\title{
Kluyveromyces nonfermentans sp. nov., a new yeast species isolated from the deep sea
}

\author{
Takahiko Nagahama, ${ }^{1}$ Makiko Hamamoto, ${ }^{2}$ Takashi Nakase ${ }^{1}$ \\ and Koki Horikoshi ${ }^{1}$
}

\author{
Author for correspondence: Takahiko Nagahama. Tel: +8146867 5556. Fax: +81468666364 \\ e-mail: nagahama@jamstec.go.jp
}

\footnotetext{
1 Deep-sea Microorganism Research Group, Japan Marine Science and Technology Center (JAMSTEC), 2-15 Natsushima-cho, Yokosuka 237-0061, Japan

2 Japan Collection of Microorganisms, The Institute of Physical and Chemical Research (RIKEN), Wako, Saitama 351-0198, Japan
}

\begin{abstract}
Eleven strains of a new species of the genus Kluyveromyces, characterized as having evanescent asci and Q-6 as the major ubiquinone, were isolated from sediments, a clam and a crab collected at depths of 1000-2000 m in Suruga Bay and Sagami Bay, Japan. A phylogenetic tree based on small-subunit (18S) rRNA gene sequences placed these isolates into a cluster of Kluyveromyces. DNA complementarity and phylogenetic trees of internal transcribed spacer (ITS) regions and 5.85 rRNA genes showed that the isolates are closely related to Kluyveromyces aestuarii, but that these two species are genetically distinct. The isolates are described as Kluyveromyces nonfermentans sp. nov. Because this species lacks the fermentative ability considered to be an important criterion for the genus Kluyveromyces, the definition of the genus has been emended. The type strain of $K$. nonfermentans is strain SY-33' (= JCM 10232').
\end{abstract}

Keywords: Kluyveromyces nonfermentans sp. nov., 18S rDNA, 5·8S rDNA, internal transcribed spacer, deep-sea isolates

\section{INTRODUCTION}

In the past, yeasts in marine environments have been investigated by many microbiologists and some of these have been recognized as new species (e.g. Rodrigues de Miranda \& Norkrans, 1968; Fell \& Statzell, 1971). Difficulties involved in collecting muds or organisms from deep-sea environments have limited most research to the shallower areas of the sea (Fell, 1976). We have isolated a number of micro-organisms from deep-sea samples obtained by the manned submersibles 'Shinkai 2000' and 'Shinkai 6500' and the unmanned submersible 'Kaiko' (Kato et al., 1996; Takami et al., 1997). Many yeasts were present among these microbes, including strains tolerant of organic solvents (Fukumaki et al., 1994). We examined more than 100 yeast strains isolated from sediments and benthic organisms obtained from deep-sea environments and found 11 strains of a previously unknown species of the genus Kluyveromyces, described in this paper as Kluyveromyces nonfermentans sp. nov.

Abbreviation: ITS, internal transcribed spacer.

The DDBJ accession numbers for the 18S rDNA sequences reported in this paper are $A B 011507-A B 011510, A B 011512-A B 011521$ and $A B 012264$.

\section{METHODS}

Isolation. Yeasts were isolated from frozen deep-sea samples on YM agar (Difco) dissolved in artificial seawater $\left(3 \% \quad \mathrm{NaCl}, 0.07 \% \mathrm{KCl}, \quad 1.08 \% \quad \mathrm{MgCl}_{2} \cdot 6 \mathrm{H}_{2} \mathrm{O}, 0.54 \%\right.$ $\mathrm{MgSO}_{4} .7 \mathrm{H}_{2} \mathrm{O}, 0.1 \% \quad \mathrm{CaCl}_{2} .2 \mathrm{H}_{2} \mathrm{O}$ ) supplemented with $0.01 \%$ chloramphenicol and $0.002 \%$ streptomycin. The agar plates were incubated at a low temperature $\left(5-10^{\circ} \mathrm{C}\right)$ for the first 2 weeks and then at $20^{\circ} \mathrm{C}$ for 1 month. All strains were grown at $25^{\circ} \mathrm{C}$ in YM broth (Difco) or on YM agar (Difco) for purification and cultivation. The strains used in this study are listed in Table 1.

Physiological and biochemical characteristics. Strains were characterized morphologically and physiologically by standard methods with some modifications (van der Walt \& Yarrow, 1984). Assimilation of nitrogen compounds was examined on solid media using a starved inoculum (Nakase \& Suzuki, 1986). The vitamin requirements were investigated according to the methods of Komagata \& Nakase (1967). Ubiquinones were extracted by the method of Yamada \& Kondo (1973) with slight modifications and analysed by HPLC (Tamaoka et al., 1983).

Nucleic acid analyses. DNA extraction and purification for DNA base composition and DNA reassociation analyses were performed by the procedure of Hamamoto \& Nakase (1995) with slight modifications. DNA base composition was determined by the HPLC method of Tamaoka \& Komagata (1984). DNA-DNA hybridization experiments 
Table 1. Strains used in this study

\begin{tabular}{|c|c|c|c|c|c|}
\hline Species & Strain & Isolate no. & Source & Locality & Accession no. \\
\hline \multirow[t]{11}{*}{ K. nonfermentans } & JCM 10226 & SY-05 & Sediment at depth of $1200-1977 \mathrm{~m}$ & Suruga or Sagami Bay & - \\
\hline & JCM 10227 & SY-19 & Sediment at depth of $1200-1977 \mathrm{~m}$ & Suruga or Sagami Bay & AB011507 \\
\hline & JCM 10228 & SY-20 & Sediment at depth of $1200-1977 \mathrm{~m}$ & Suruga or Sagami Bay & - \\
\hline & JCM 10229 & SY-26 & Sediment at depth of $1200-1977 \mathrm{~m}$ & Suruga or Sagami Bay & - \\
\hline & JCM 10230 & SY -28 & Sediment at depth of $1200-1977 \mathrm{~m}$ & Suruga or Sagami Bay & AB011508 \\
\hline & JCM 10231 & SY-29 & Sediment at depth of $1200-1977 \mathrm{~m}$ & Suruga or Sagami Bay & АВ011509 \\
\hline & $\mathrm{JCM} 10232^{\mathrm{T}}$ & SY $-33^{\mathrm{T}}$ & Sediment at depth of $1200-1977 \mathrm{~m}$ & Suruga or Sagami Bay & AB012264 \\
\hline & JCM 10233 & SY-54 & Sediment at depth of $1143 \mathrm{~m}$ & Suruga Bay & - \\
\hline & JCM 10234 & SY-56 & Crab at depth of $1182 \mathrm{~m}$ & Suruga Bay & AB011510 \\
\hline & JCM 10235 & SY-63 & Calyptogena sp. at depth of $1156 \mathrm{~m}$ & Suruga Bay & - \\
\hline & JCM 10236 & SY-64 & Calyptogena sp. at depth of $1156 \mathrm{~m}$ & Suruga Bay & AB011512 \\
\hline K. aestuarii & IFO $10597^{\mathrm{T}}$ & - & CBS $4438^{\mathrm{T}}$ & - & AB011513 \\
\hline K. dobzhanskii & IFO $10603^{T}$ & - & CBS $2104^{T}$ & - & AB011514 \\
\hline \multirow[t]{3}{*}{ K. lactis } & IFO $1090^{\mathrm{T}}$ & - & NCYC $416^{T}$ & - & AB011515 \\
\hline & JCM 6846 & - & NCYC 1548 & - & AB011516 \\
\hline & JCM 9563 & - & IFO 0648 & - & AB011517 \\
\hline \multirow[t]{3}{*}{ K. marxianus } & IFO $10005^{\mathrm{T}}$ & - & CBS $712^{\mathrm{T}}$ & - & AB011518 \\
\hline & JCM 1630 & - & IAM 12237 & - & AB011519 \\
\hline & JCM 2188 & - & IAM 12830 & - & $\mathrm{AB} 011520$ \\
\hline K. wickerhamii & IFO $1675^{\mathrm{T}}$ & - & CBS $2745^{\mathrm{T}}$ & - & AB011521 \\
\hline
\end{tabular}

were performed using DNA-fixed microplates, by the procedures described by Ezaki et al. (1989).

Phylogenetic analysis. DNA extraction for PCR was performed as described below. One loop of yeast culture was suspended in extraction buffer $(200 \mathrm{mM}$ Tris $/ \mathrm{HCl}, \mathrm{pH} 8.5$, $250 \mathrm{mM} \mathrm{NaCl}, 25 \mathrm{mM}$ EDTA, $0.5 \%$ SDS) and ground using a pellet mixer (Tref). The nucleic acids to be used as a template for PCR were extracted by phenol/chloroform treatment and propan-2-ol precipitation. The primers used for amplification and sequencing of $18 \mathrm{~S}$ rRNA, 5.8S rRNA and the internal transcribed spacer (ITS) region were those described by White et al. (1990). The PCR products were purified by means of Suprec TM-02 (Takara) and sequenced using a LI-COR DNA sequencer model 4000L. All sequences were aligned using CLUSTAL w 1.75 (Thompson $e t$ al., 1994) and were adjusted manually. Positions where one or more species contained a length mutation and where the sequences were unalignable were not included in the distance analysis. The evolutionary distances were calculated using the PHYLIP 3.57c program DNADIST (Felsenstein, 1995) with Kimura's two-parameter model and the trees were constructed in NEIGHBOR by the neighbour-joining method (Saitou \& Nei, 1987). The robustness of branches in the tree was evaluated by performing a bootstrap analysis (Felsenstein, 1985) with 1000 replicates.

The sequences determined were deposited in the DDBJ database under the accession numbers shown in Table 1.

\section{RESULTS AND DISCUSSION}

Eleven strains isolated from sediments, a giant white clam (Calyptogena sp.) and an unidentified crab collected at depths of $1000-2000 \mathrm{~m}$ in Suruga Bay or Sagami Bay, Japan, were identified as species of the genus Kluyveromyces on the basis of formation of evanescent asci (Fig. 1) and having Q-6 as the major ubiquinone. The morphological, physiological and biochemical characteristics of these 11 isolates were nearly identical but, on the basis of heterogeneity in assimilation of three carbon compounds, cellobiose, salicin and ribitol, four sub-groups were recognized (SY-05, SY-20, SY-26, SY-28 and SY-29; SY-54, SY56, SY-63 and SY-64; SY-19; and SY-33 ${ }^{\mathrm{T}}$.

\section{Phylogenetic analysis}

We determined the 18S rRNA gene sequences of five isolates, SY-19, SY-28, SY-29, SY-33 ${ }^{\mathrm{T}}$ and SY-56, to establish their taxonomic placement within the genus Kluyveromyces, which is recognized as a relatively large genus consisting of 15 species. The five sequences were completely identical and were aligned with the published sequences of 33 ascomycetous yeasts, all of which contained Q-6 as the major ubiquinone, with the exception of Holleya sinecauda, which has Q-9, and Debaryomyces hansenii var. hansenii as an outgroup. A phylogenetic tree constructed by the neighbour-joining method (Saitou \& Nei, 1987) on the basis of the 1636 positions alignable in all species is shown in Fig. 2. Our tree topology was consistent with the upper part of that previously reported (Cai et al., 1996), except for some differences in branching with low confidence values of bootstrapping, consistent with the knowledge that the genus Kluyveromyces is a polyphyletic group (Cai et al., 1996). The five isolates, SY-19, SY-28, SY$29, S Y-33^{\mathrm{T}}$ and $\mathrm{SY}-56$, were precisely placed in cluster 2 described by Cai et al. (1996), comprising Kluyveromyces aestuarii, Kluyveromyces dobzhanskii, Kluyveromyces lactis, Kluyveromyces marxianus and 

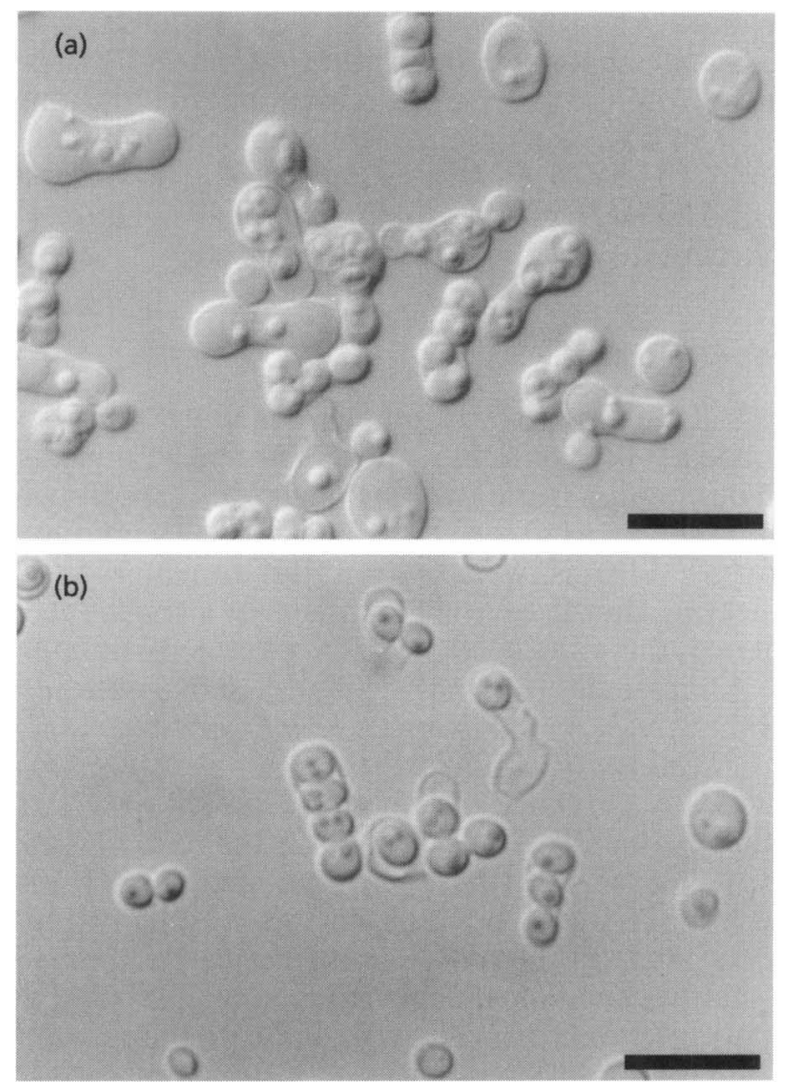

Fig. 1. Photomicrographs of $K$. nonfermentans SY- $33^{\top}(=J C M$ $10232^{\top}$ ) on YM agar. (a) Vegetative cells and asci after $3 \mathrm{~d}$ at $25^{\circ} \mathrm{C}$. (b) Disrupted asci after 3 weeks at $25^{\circ} \mathrm{C}$. Bars, $10 \mu \mathrm{m}$.

Kluyveromyces wickerhamii, closer to K. aestuarii than to the other species in this cluster. Cluster 2, including the five isolates, was clearly distinguished from the others with a significant level $(100 \%)$ of bootstrap confidence, in agreement with the previous report (Cai et al., 1996).

To clarify the relationships within cluster 2 further, we determined and analysed the sequences of the ITS region and the 5.8S rRNA gene of 15 strains, i.e. the type strains of $K$. aestuarii, $K$. dobzhanskii and $K$. wickerhamii, three strains of $K$. marxianus, three strains of $K$. lactis and six isolates, SY-19, SY-28, SY-29, SY$33^{\mathrm{T}}$, SY-56 and SY-64, selected from the four subgroups recognized on the basis of the results of assimilation tests. Because the ITS region displays a high substitution rate relative to the $18 \mathrm{~S}$ and $26 \mathrm{~S}$ rRNA genes, it has been found to be useful in resolving relationships between close taxonomic relatives (Berbee et al., 1995; Waalwijk et al., 1996; James et al., 1996; Oda et al., 1997). Phylogenetic trees based on ITS1-5.8S rDNA-ITS2, ITS1 and ITS2 are shown in Figs 3(a), (b) and (c), respectively. No intraspecific variation in ITS sequences was evident among the six isolates or among three strains of $K$. marxianus, in contrast to three strains of $K$. lactis. All trees successfully placed the 15 strains examined here into each

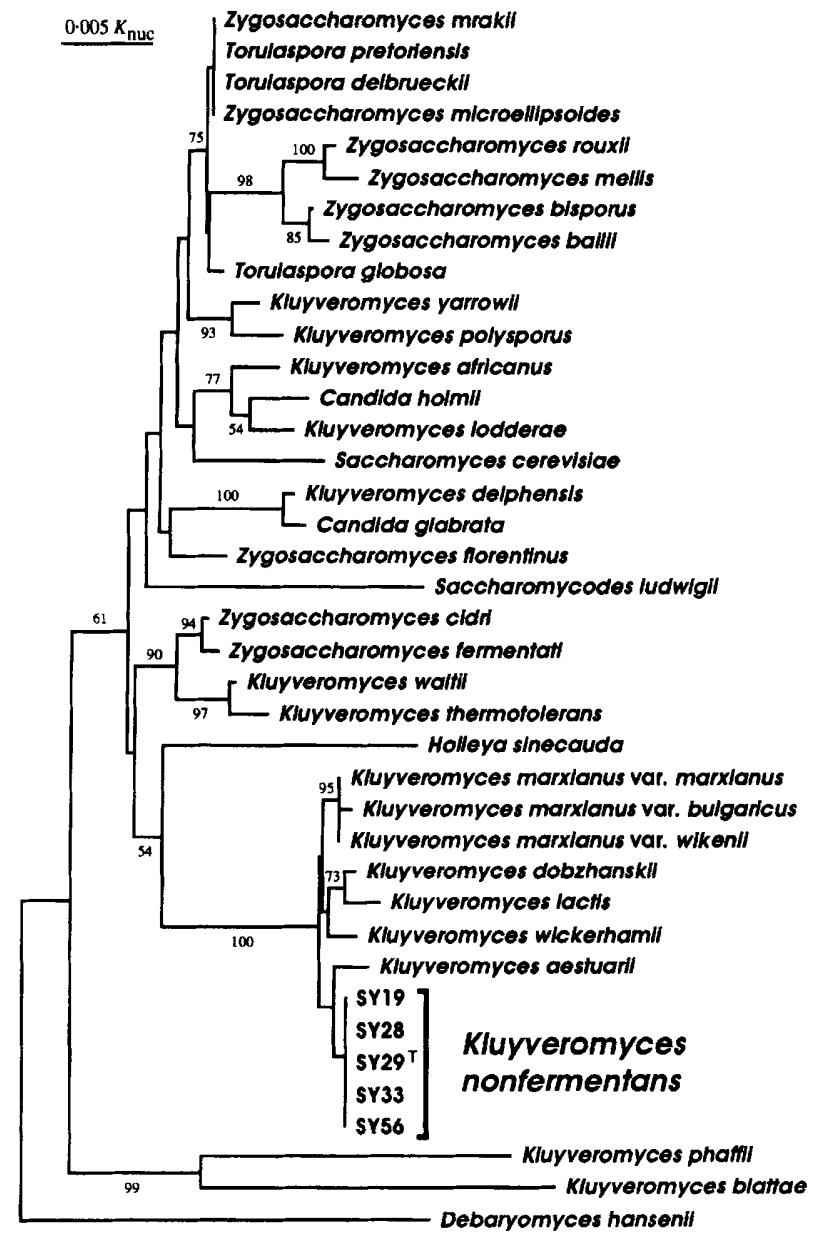

Fig. 2. Phylogenetic positions of five $K$. nonfermentans isolates, inferred from 18S rRNA gene sequences. The tree was constructed as described in the text. Numbers by nodes are bootstrap frequencies (values $<50 \%$ not shown) derived from 1000 replicates. The accession numbers of reference sequences used in this tree are: $Z$. mrakii, X90757; $T$. pretoriensis, X84638; T. delbrueckii, X53496; Z. microellipsoides, X90756; Z. rouxii, X90758; Z. mellis, X90755; Z. bisporus, X91084; Z. bailii, X91083; T. globosa, X84639; K. yarrowii, X89528; K. polysporus, X83825; K. africanus, X89519; C. holmii, X78601; K. lodderae, $X 83824 ; S$. cerevisiae, $M 27607 ; K$. delphensis, $X 83823 ; C$. glabrata, X51831; Z. florentinus, X91086; S. ludwigii, X69843; $Z$. cidri, X91085; Z. fermentati, X77930; K. waltii, X89527; K. thermotolerans, X89526; $H$. sinecauda, U53443; $K$. marxianus var. marxianus, X89523; K. marxianus var. bulgaricus, X89524; K. marxianus var. wikenii, X89522; K. dobzhanskii, X83822; $K$. lactis, X51830; K. wickerhamii, X83826; K. aestuarii, X89520; $K$. phaffii, X89525; K. blattae, X89521; and D. hansenii, X58053.

species, but differences in tree topologies were evident due to ambiguity with respect to the branching point of $K$. dobzhanskii. The SY strains were placed closer to $K$. aestuarii in these trees, in agreement with the placement observed in the 18S-based tree (Fig. 2). Evolutionary distances between species determined on the basis of ITS1 were longer than those obtained on the basis of ITS2, whereas a remarkably long branch between the $K$. aestuarii-SY strains cluster and the other cluster was obtained on the basis of ITS2. Also, two of four 

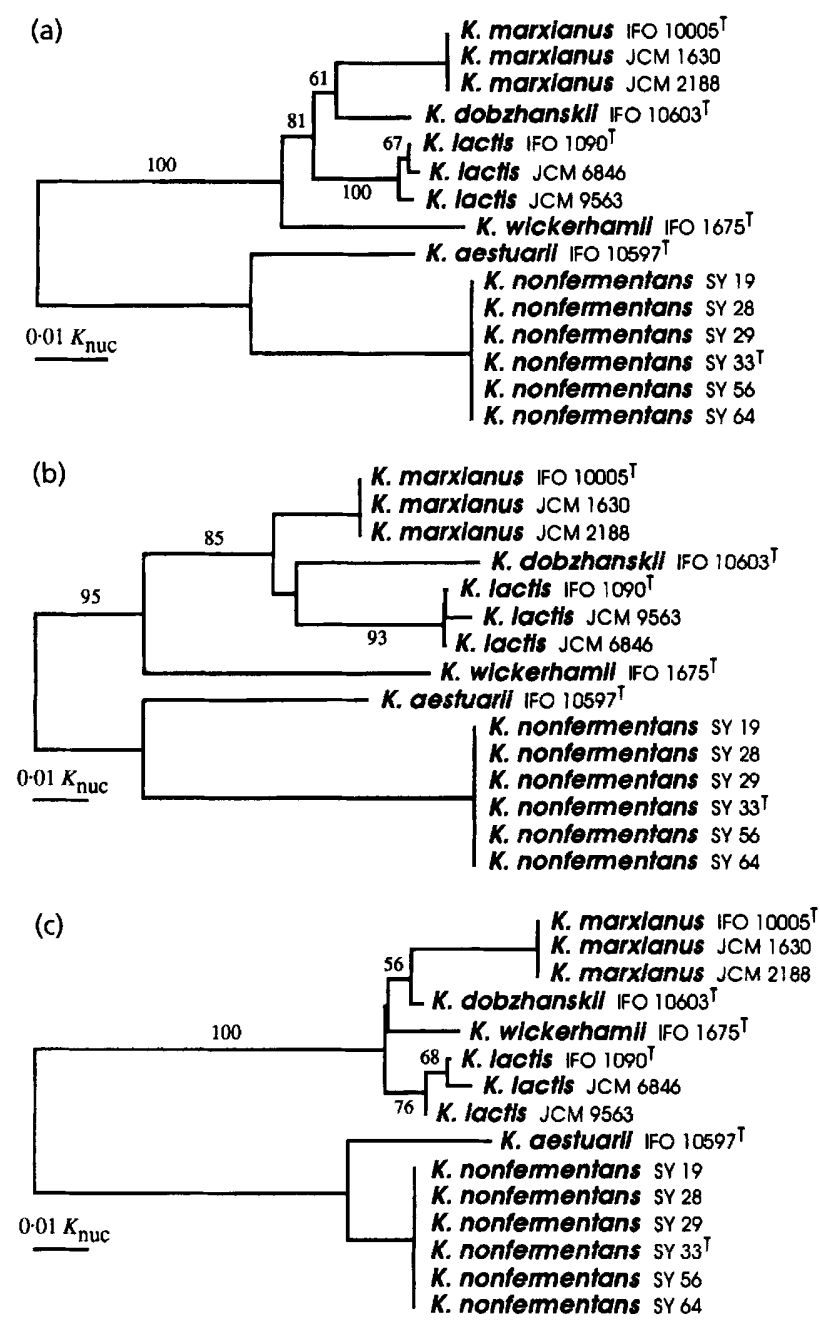

Fig. 3. Phylogenetic relationships among strains of $K$. nonfermentans and related species. The trees were constructed from the evolutionary distance data for ITS1-5.8S rDNA-ITS2 (a), ITS1 (b) and ITS2 (c), as described in the text. Numbers by nodes are bootstrap frequencies (values $<50 \%$ not shown) derived from 1000 replicates. substitutions in the 5.8S rRNA gene occurred within the branch that separated the $K$. aestuarii-SY strains cluster from the others. The remaining substitutions in the $5.8 \mathrm{~S}$ rRNA gene were within the branches that led to both the SY strains and $K$. aestuarii. The variations in the $5.8 \mathrm{~S}$ rRNA gene could be useful as signatures for differentiation of the three groups.

\section{DNA-DNA reassociation}

DNA-DNA reassociation experiments were performed at $40^{\circ} \mathrm{C}$ among strains identified within cluster 2 in our phylogenetic analysis. The results are shown in Table 2. The relative DNA binding values among the four SY strains were within the range $91-107 \%$, indicating that these were members of a single species, whereas the values of $22-52 \%$ obtained for DNADNA reassociation among SY-33 $3^{\mathrm{T}}$ and six strains of $K$. marxianus, $K$. dobzhanskii, $K$. lactis, $K$. wickerhamii and $K$. aestuarii confirmed that the SY strains were genetically unrelated to previously known species. The highest value of $52 \%$ obtained in the case of DNADNA reassociation between $K$. aestuarii IFO 10597 and SY $-33^{\mathrm{T}}$ was consistent with the results of phylogenetic analysis. The correspondence between the ITSbased trees and the values obtained in the DNA-DNA reassociation experiments may indicate the possibility of employing ITS sequences as a taxonomic tool for delineating species.

\section{Genus Kluyveromyces van der Walt emend. Nagahama, Hamamoto, Nakase et Horikoshi}

Asexual reproduction is by multilateral budding on a narrow base. Cells are ovoid, ellipsoid, cylindrical to elongate. Pseudomycelium may be formed. True hyphae are not produced. Conjugation may or may not precede ascus formation. The ascospores are smooth, reniform, bacilliform, ellipsoidal or spheroidal, tending to agglutinate after liberation. One to

Table 2. Levels of DNA complementarity among strains of $K$. nonfermentans and related species

\begin{tabular}{|c|c|c|c|c|c|c|c|c|c|c|c|}
\hline \multirow[t]{2}{*}{ Species } & \multirow[t]{2}{*}{ Strain } & \multicolumn{10}{|c|}{ Relative binding (\%) to DNA from: } \\
\hline & & 1 & 2 & 3 & 4 & 5 & 6 & 7 & 8 & 9 & 10 \\
\hline 1. K. nonfermentans & SY-19 & 100 & 97 & 95 & 93 & 28 & - & - & - & - & - \\
\hline 2. $K$. nonfermentans & SY -28 & 93 & 100 & 97 & 91 & 30 & - & - & - & - & - \\
\hline 3. $K$. nonfermentans & SY-56 & 101 & 107 & 100 & 96 & 28 & - & - & - & - & - \\
\hline 4. $K$. nonfermentans & $S Y-33^{T}$ & 102 & 105 & 105 & 100 & 42 & 22 & 41 & 25 & 38 & 52 \\
\hline 5. K. marxianus & JCM 1630 & 43 & 38 & 38 & 41 & 100 & 100 & 57 & 41 & 37 & 39 \\
\hline 6. K. marxianus & IFO $10005^{\mathrm{T}}$ & - & - & - & 37 & 101 & 100 & 44 & 42 & 22 & 33 \\
\hline 7. K. dobzhanskii & IFO $10603^{\mathrm{T}}$ & - & - & - & 32 & 57 & 48 & 100 & 53 & 41 & 41 \\
\hline 8. K. lactis & IFO $1090^{\mathrm{T}}$ & - & - & - & 36 & 49 & 44 & 57 & 100 & 19 & 34 \\
\hline 9. K. wickerhamii & IFO $1675^{\mathrm{T}}$ & - & - & - & 26 & 40 & 31 & 39 & 24 & 100 & 27 \\
\hline 10. K. aestuarii & IFO $10597^{\mathrm{r}}$ & - & - & - & 46 & 38 & 32 & 34 & 36 & 21 & 100 \\
\hline
\end{tabular}


Table 3. Physiological and biochemical characteristics that differentiate $K$. nonfermentans from related species

$\mathrm{v}$, Variable; w, weak.

\begin{tabular}{|c|c|c|c|c|c|c|}
\hline Characteristic & K. nonfermentans & K. aestuarii & K. dobzhanskii & K. lactis & K. marxianus & K. wickerhamii \\
\hline \multicolumn{7}{|l|}{ Assimilation of: } \\
\hline Saccharose & - & + & + & + & + & + \\
\hline Glycerol & - & + & + & + & $\mathrm{v}$ & + \\
\hline Lactic acid & - & + & + & + & + & + \\
\hline Succinic acid & - & + & + & + & + & + \\
\hline Fermentation of D-glucose & - & + & + & $\mathrm{v}$ & + & + \\
\hline Growth in the absence of thiamin & $-/ \mathrm{w}$ & + & + & + & + & + \\
\hline DNA G $+C$ content $(\mathrm{mol} \%)$ & $35 \cdot 8-37 \cdot 4$ & $39 \cdot 5-39 \cdot 9$ & $42 \cdot 6$ & $39 \cdot 9-40 \cdot 7$ & $40 \cdot 8-41 \cdot 5$ & $40 \cdot 0-42 \cdot 4$ \\
\hline
\end{tabular}

four or, in some species, many ascospores are formed per ascus. Fermentation is usually present. Nitrate is not assimilated. Diazonium blue $B$ reaction is negative. This description is based on that of Lachance (1998).

\section{Latin diagnosis of Kluyveromyces nonfermentans sp. nov.}

In medio liquido post dies 3 cellulae vegetativae spheroideae vel ellipsoideae $(2.0-6.5 \times 2.0-7.5 \mu \mathrm{m})$, singlae vel binae. Post unum mensem sedimentum formatur. Cultura in agaro YM, infimo-convexa, glabra vel verruculosa, pauro hebia, cremea vel glauco-cremea, butyrosa et margine glabra, undulata vel lobiforma. Hyphae et pseudohyphae non formantur. Post dies 3 in agaro YM aut malti (5\%), asci formantur, evanescentes post dies 14. Asci conjugati, habentes 1-4, sporos spheroides. Fermentatio nulla. Galactosum, cellobiosum (varium), lactosum (vel exiguum), ethanolum, Dmannitolum et salicinum (varium) assimilantur, at non L-sorbosum, saccharosum, maltosum, trehalosum, melibiosum, raffinosum, melezitosum, inulinum, amylum solubile, D-xylosum, L-arabinosum, D-arabinosum, Dribosum, L-rhamnosum, glycerolum, erythritolum, ribitolum (varium), galactitolum, D-glucitolum, methyl $\alpha$-D-glucosidum, glucono- $\delta$-lactonum, acidum 2-ketogluconicum, acidum 5-ketogluconicum, acidum DLlacticum (aut exiguum), acidum succinicum, acidum citricum, inositolum, acidum D-glucuronicum nec acidum D-galacturonicum. Ethylaminum, lysinum et cadaverinum assimilantur at non kalium nitricum nec natrium nitricum. Ad crescentiam biotinum, niacinum et thiaminum necessarium sunt. $\mathrm{G}+\mathrm{C}$ acidi deoxyribonucleati $35 \cdot 8-37 \cdot 4 \mathrm{~mol} \%$. Ubiquinonum majus Q-6. Typus stirps SY-33 ex luta, Suruga Bay, Japan, isolata est. In collectionibus culturarum quas Japan Collection of Microorganisms, Wako, Saitama sustentant, no. JCM 10232 deposita est.

\section{Description of Kluyveromyces nonfermentans sp. nov.}

Kluyveromyces nonfermentans (non.fer.men'tans. L. adj. nonfermentans not causing fermentation).
After $3 \mathrm{~d}$ at $25^{\circ} \mathrm{C}$ in YM broth (Difco), the cells are spheroidal to ellipsoidal $(2 \cdot 0-6.5 \times 2 \cdot 0-7 \cdot 5 \mu \mathrm{m})$ and occur singly or in parent-bud pairs. A sediment is formed after 1 month. After 1 month at $25^{\circ} \mathrm{C}$ on YM agar, streak cultures are low-convex, smooth or verrucose, somewhat dull, cream to greyish-cream and butyrous. The margin is smooth, undulating to lobiform. Branching hyphae or pseudohyphae are not formed in Dalmau plate cultures on cornmeal agar (Difco). Asci, usually formed with conjugation, are evanescent and form one to four spheroidal ascospores. Sporulation is abundant on $5 \%$ malt extract (Difco) or YM agar after $2-3 \mathrm{~d}$ at $25^{\circ} \mathrm{C}$. Fermentative ability is negative. The following carbon compounds are assimilated: D-glucose, galactose, cellobiose (variable), lactose (or weak), ethanol, Dmannitol and salicin (variable). No growth occurs on L-sorbose, saccharose, maltose, trehalose, melibiose, raffinose, melezitose, inulin, soluble starch, D-xylose, L-arabinose, D-arabinose, D-ribose, L-rhamnose, glycerol, erythritol, ribitol (variable), galactitol, Dglucitol, methyl $\alpha$-D-glucoside, glucono- $\delta$-lactone, 2 ketogluconic acid, 5-ketogluconic acid, lactic acid (or weak), succinic acid, citric acid, inositol, D-glucuronic acid or D-galacturonic acid. The following nitrogen compounds are assimilated: ethylamine, lysine and cadaverine. No growth occurs on sodium nitrate or sodium nitrite. The vitamins required are biotin (no growth or weak), niacin and thiamin (no growth or weak). Growth at $37^{\circ} \mathrm{C}$ is variable. No growth occurs on $50 \%$ glucose-yeast extract agar. Growth occurs on YM agar containing $10 \% \mathrm{NaCl}$. No growth occurs in the presence of 100 p.p.m. cycloheximide. Starch-like substances are not produced. Gelatin liquefaction is negative. Splitting of fat is negative. The diazonium blue $B$ reaction is negative. Urease activity is negative. The major ubiquinone is $\mathrm{Q}-6$. The $\mathrm{G}+\mathrm{C}$ content of the nuclear DNA is $35.8-37.4 \mathrm{~mol} \%$. The type strain of Kluyveromyces nonfermentans, strain SY-33 ${ }^{\mathrm{T}}$, was isolated from deep-sea mud in Suruga Bay or Sagami Bay, Japan. This strain has been deposited in the Japan Collection of Microorganisms (JCM), the Institute of Physical and Chemical Research (RIKEN), Wako, Saitama, Japan, as strain JCM $10232^{\mathrm{T}}$. The other 10 
strains examined, SY-05, SY-19, SY-20, SY-26, SY28, SY-29, SY-54, SY-56, SY-63 and SY-64, are also deposited in the JCM, as JCM 10226, JCM 10227, JCM 10228, JCM 10229, JCM 10230, JCM 10231, JCM 10233, JCM 10234, JCM 10235 and JCM 10236, respectively.

\section{Additional information}

The name Kluyveromyces nonfermentans sp. nov. is proposed for the 11 non-fermenting strains described here in consideration of their remarkable lack of fermentative ability in comparison with other Kluyveromyces species. With the description of $K$. nonfermentans $\mathrm{sp}$. nov., the genus Kluyveromyces has been emended as given above.

$K$. nonfermentans, a new species from deep-sea environments, can be distinguished from the other cluster-2 species, $K$. marxianus, $K$. dobzhanskii, $K$. lactis, $K$. wickerhamii and $K$. aestuarii, on the basis of the lack of assimilation of sucrose, lactic acid and succinic acid as a sole carbon compound and lack of fermentation of D-glucose (Table 3 ). The $\mathrm{G}+\mathrm{C}$ content of the DNA of $K$. nonfermentans, within the range $35.8-37.4 \mathrm{~mol} \%$, is relatively low compared with that of the other cluster-2 species (Table 3 ), but this may be due to the use of different protocols for determination of DNA base composition.

$K$. aestuarii, a species phylogenetically related to $K$. nonfermentans, appears to be associated with saline water, mud and some invertebrates in estuaries or other marine environments (Fell, 1961; Ahearn et al., 1968; de Araujo et al., 1995). The coincident occurrence of $K$. nonfermentans and $K$. aestuarii, which appears to be restricted to marine environments, supports the view that these two species may have shared a common ancestor in the aquatic environment. A characteristic discontinuity between $K$. nonfermentans and the other cluster-2 species, including $K$. aestuarii, has led to the hypothesis that $K$. nonfermentans may be originally derived from a $K$. aestuaril-like organism that evolved through adaptation to deeper regions of marine environments.

\section{ACKNOWLEDGEMENTS}

We are indebted to Yuichi Nogi for his skilful technical assistance.

\section{REFERENCES}

Ahearn, D. G., Roth, F. J. \& Meyers, S. P. (1968). Ecology and characterization of yeasts from aquatic regions of South Florida. Mar Biol 36, 291-308.

de Araujo, F. V., Soares, C. A. G., Hagler, A. N. \& MendonçaHagler, L. C. (1995). Ascomycetous yeast communities of marine invertebrates in a southeast Brazilian mangrove ecosystem. Antonie Leeuwenhoek 68, 91-99.

Berbee, M. L., Yoshimura, A., Sugiyama, J. \& Taylor, J. W. (1995).
Is Penicillium monophyletic? An evaluation of phylogeny in the family Trichocomaceae from $18 \mathrm{~S}, 5 \cdot 8 \mathrm{~S}$ and ITS ribosomal DNA sequence data. Mycologia 87, 210-222.

Cai, J., Roberts, I. N. \& Collins, M. D. (1996). Phylogenetic relationships among members of the ascomycetous yeast genera Brettanomyces, Debaryomyces, Dekkera, and Kluyveromyces deduced by small-subunit rRNA gene sequences. Int $J$ Syst Bacteriol 46, 542-549.

Ezaki, T., Hashimoto, Y. \& Yabuuchi, E. (1989). Fluorometric deoxyribonucleic acid-deoxyribonucleic acid hybridization in microdilution wells as an alternative to membrane filter hybridization in which radioisotopes are used to determine genetic relatedness among bacterial strains. Int $J$ Syst Bacteriol 39, 224-229.

Fell, J. W. (1961). A new species of Saccharomyces isolated from a subtropical estuary. Antonie Leeuwenhoek 27, 27-30.

Fell, J. W. (1976). Yeast in oceanic regions. In Recent Advances in Aquatic Mycology, pp. 93-124. Edited by E. B. G. Jones. London: Elek Science.

Fell, J.W. \& Statzell, A. C. (1971). Sympodiomyces gen. n., a yeast-like organism from southern marine waters. Antonie Leeuwenhoek 37, 359-367.

Felsenstein, J. (1985). Confidence limit on phylogenies: an approach using the bootstrap. Evolution 39, 783-791.

Felsenstein, J. (1995). PHYLIP - Phylogenetic inference package, version $3.57 \mathrm{c}$. Seattle: University of Washington.

Fukumaki, T., Inoue, A., Moriya, K. \& Horikoshi, K. (1994). Isolation of a marine yeast that degrades hydrocarbon in the presence of organic solvent. Biosci Biotechnol Biochem 58, 1784-1788.

Hamamoto, M. \& Nakase, T. (1995). Ballistosporous yeasts found on the surface of plant materials collected in New Zealand. 1. Six new species in the genus Sporobolomyces. Antonie Leeuwenhoek 67, 151-171.

James, S. A., Collins, M. D. \& Roberts, I. N. (1996). Use of an rRNA internal transcribed spacer region to distinguish phylogenetically closely related species of the genera Zygosaccharomyces and Torulaspora. Int J Syst Bacteriol 46, 189-194.

Kato, C., Masui, N. \& Horikoshi, K. (1996). Properties of obligately barophilic bacteria isolated from a sample of deep-sea sediment from the Izu-Bonin Trench. $J$ Mar Biotechnol 4, 96-99.

Komagata, K. \& Nakase, T. (1967). Reitoshokuhin no biseibutsu ni kansuru kenkyu. V. Shihan reitoshokuhin yori bunri shita kobo no seijo (Microbiological studies on frozen foods). Shokuhin Eiseigaku Zasshi 8, 53-57 (in Japanese).

Lachance, M. A. (1998). Kluyveromyces. In The Yeasts, a Taxonomic Study, 4th edn, pp. 227-247. Edited by C. P. Kurtzman \& J. W. Fell. Amsterdam: Elsevier Science.

Nakase, T. \& Suzuki, M. (1986). Bullera megalospora, a new species of yeast forming large ballistospores isolated from dead leaves of Oryza sativa, Miscanthus sinensis and Sasa sp. in Japan. J Gen Appl Microbiol 32, 225-240.

Oda, Y., Yabuki, M., Tonomura, K. \& Fukunaga, M. (1997). Reexamination of yeast strains classified as Torulaspora delbrueckii (Lindner). Int J Syst Bacteriol 47, 1102-1106.

Rodrigues de Miranda, L. \& Norkrans, B. (1968). Candida suecica sp. n. isolated from marine environment. Antonie Leeuwenhoek 34, 115-118.

Saitou, N. \& Nei, M. (1987). The neighbor-joining method: a new method for reconstructing phylogenetic trees. Mol Biol Evol 4, $406-425$. 
Takami, H., Inoue, A., Fuji, F. \& Horikoshi, K. (1997). Microbial flora in the deepest sea mud of the Mariana Trench. FEMS Microbiol Lett 152, 279-285.

Tamaoka, J. \& Komagata, K. (1984). Determination of DNA base composition by reversed-phase high-performance liquid chromatography. FEMS Microbiol Lett 25, 125-128.

Tamaoka, J., Katayama-Fujimura, Y. \& Kuraishi, H. (1983). Analysis of bacterial menaquinone mixtures by high performance liquid chromatography. $J$ Appl Bacteriol 54, 31-36.

Thompson, J. D., Higgins, D. G. \& Gibson, T. S. (1994). CLUSTAL $\mathrm{W}$ : improving the sensitivity of progressive multiple sequence alignment through sequence weighting, position-specific gap penalties and weight matrix choice. Nucleic Acids Res 22, 4673-4680.

Waalwijk, C., de Koning, J. R. A., Baayen, R. P. \& Gams, W. (1996). Discordant groupings of Fusarium spp. from sections Elegans,
Liseola and Dlaminia based on ribosomal ITS1 and ITS2 sequences. Mycologia 88, 361-368.

van der Walt, J. P. \& Yarrow, D. (1984). Methods for the isolation, maintenance, classification and identification of yeasts. In The Yeasts, a Taxonomic Study, 3rd edn, pp. 45-104. Edited by N. J. W. Kreger-van Rij. Amsterdam: Elsevier Science.

White, T. J., Bruns, T., Lee, S. \& Taylor, J. W. (1990). Amplification and direct sequencing of fungal ribosomal RNA genes for phylogenetics. In PCR Protocols, pp. 315-322. Edited by M. Innis, D. Gelfand, J. J. Sninsky \& T. J. White. San Diego: Academic Press.

Yamada, Y. \& Kondo, K. (1973). Coenzyme Q system in the classification of the yeast genera Rhodotorula and Cryptococcus and the yeast-like genera Sporobolomyces and Rhodosporidium. $J$ Gen Appl Microbiol 19, 59-77. 